\title{
Pemilah dan Penghitung Uang Logam Berdasarkan Diameter Menggunakan Sensor TCRT5000
}

\section{The Coin Sorter and Counter based on Diameter using TCRT5000 Sensor}

\author{
Slamet Indriyanto ${ }^{1, *}$, Rahmat Widadi $^{2}$, Luhur Pamukti $^{3}$ \\ ${ }^{1,3}$ Program Studi S1 Teknik Telekomunikasi, ${ }^{2}$ Program Studi Teknik Biomedis, \\ Fakultas Teknik Telekomunikasi dan Elektro, Institut Teknologi Telkom Purwokerto \\ Jl. D.I. Panjaitan No.128 Purwokerto, Jawa Tengah, Indonesia \\ 1,*Penulis Korespondensi : slamet@ittelkom-pwt.ac.id, \\ ${ }^{2}$ rahmat@ittelkom-pwt.ac.id, ${ }^{3} 16201086 @$ ittelkom-pwt.ac.id
}

Received on 17-11-19, accepted on 29-05-20, published on 29-05-20

\begin{abstract}
Abstrak
Uang sebagaimana diketahui sebagai alat pembayaran baik barang maupun jasa, memiliki bentuk fisik dalam bentuk kertas dan logam. Uang logam Rupiah biasanya terbuat dari bahan alumunium atau nikel. Setiap kepingnya memiliki tekstur tertentu pada sisi uang untuk membedakan tiap pecahan. Di Indonesia terdapat 4 jenis uang logam yang beredar saati ini, yaitu pecahan Rp. 100, 200, 500 dan 1000 rupiah. Uang logam jika dalam jumlah banyak dan bercampur akan merepotkan jika harus dipisahkan dan dihitung satu demi satu. Untuk itu diperlukan suatu alat yang dapat berfungsi untuk memilah dan sekaligus menghitung jumlah uang logam. Pada paper ini telah dirancang dan dibuat suatu alat pemilah dan penghitung uang logam menggunakan sensor TCRT5000. Pemilahan uang logam yang ada berdasarkan diameter dari masing-masing uang logam, dan sensor digunakan untuk menghitung berapa nominal yang sudah tertampung dalam wadah yang disediakan. Hasil pengujian didapatkan dari 100 kali percobaan uang logam Rp.100 rupiah terdapat 2 percobaan tidak terdeteksi oleh sensor. Pengujian uang logam Rp200 rupiah terdapat juga 2 kali percobaan tidak tereteksi oleh sensor. Pengujian uang logam Rp.500 rupiah dan Rp.1000 rupiah tidak ada kegagalan pendeteksian ataupun penyortiran. Jadi, dari pengujian tersebut dapat disimpulkan bahwa tingkat akurasi pendeteksian uang logam Rp.100 dan Rp.200 rupiah sebesar 98\%, dan pendeteksian uang logam Rp.500 dan Rp.1000 rupiah memiliki tingkat akurasi sebesar 100\%. Dari sisi penyortiran, semua koin yang diuji bisa masuk ke dalam wadah sesuai dengan diameter dan nominal, sehingga tingkat akurasi penyortiran semua uang logam memiliki tingkat akurasi $100 \%$.
\end{abstract}

Kata kunci: Arduino UNO, Pemilah uang logam, Sensor TCRT5000

Abstract

As it is known as a means of payment for both goods and services, money has a physical form in the form of paper and metal. Rupiah coins are usually made of aluminum or nickel. Each coin has a particular texture on the coin's side to distinguish each coin. There are currently four types of coins in circulation in Indonesia, i.e., Rp. 100, 200, $\mathbf{5 0 0}$, and $\mathbf{1 0 0 0}$ rupiah. If the coins are in large quantities and mixed, they will be troublesome to be separated and counted one by one. For that, we need a tool that can function to sort and at the same time count the number of coins. In this paper, a coin sorter and counter have been designed and made using the TCRT5000 sensor. The sorting of coins is based on the diameter of each coin. While sensors are used to calculate how much nominal has been accommodated in the container provided. The test results were obtained from $100 \mathrm{Rp.100}$ rupiah coin trials. The sensor did not detect two trials. The Rp.200 rupiah coin test was also twice undetected by the sensor. The testing of Rp.500 rupiah and Rp.1000 rupiah coins did not fail to detect or sort. So, from this test, it can be concluded that 


\begin{abstract}
the detection accuracy of Rp.100 and Rp.200 rupiah coins is $98 \%$, and the detection of Rp.500 and Rp.1000 rupiah coins has an accuracy rate of $\mathbf{1 0 0 \%}$. All tested coins can fit into containers according to the diameter and nominal in terms of sorting. Therefore, sorting all coins has an accuracy rate of $100 \%$.
\end{abstract}

Keywords: Arduino UNO, Coin sorter, TCRT5000 sensor

\title{
I. Pendahuluan
}

Uang merupakan alat tukar yang dapat digunakan dan diterima oleh masyarakat luas sebagai alat pembayaran jual beli barang maupun jasa. Adanya uang memberikan alternatif untuk masyarakat dalam melakukan suatu transaksi jual beli sehingga lebih memudahkan dan efisien. Secara umum bentuk fisik uang terdiri dari dua jenis yaitu uang kertas dan uang logam. Di Indonesia, pecahan uang logam yang beredar saat ini ada 4 yaitu pecahan 100, 200, 500 dan 1000 rupiah. Untuk menghitung uang logam tinggal menghitung seperti biasa dengan memilah dan menghitung berdasarkan pecahan uang logam tersebut. Jika uang logam yang dihitung dalam jumlah sedikit, masih memungkinan untuk melakukannya secara manual. Namum, ini akan menjadi masalah jika uang yang perlu dihitung dan dipilah dalam jumlah banyak. Untuk itu diperlukan suatu alat pemilah dan penghitung untuk mempermudah proses tersebut.

Alat penghitung uang logam yang ada dipasaran memiliki harga yang tidak murah, untuk itu pada penelitian ini akan dibahas alat pemilah dan penghitung uang logam berbiaya murah. Pada penelitian ini menggunakan sensor TCRT5000 untuk mendeteksi uang logam. proses pemilahan dan penghitungan dilakukan berdasarkan diameter dari uang logam yang masuk melewati lubang sesuai dengan ukurannya. Sebagai platform hardware mikrokontroler digunakan Arduino uno R3, LCD 16x2 digunakan untuk menampilkan nominal uang logam yang terdeteksi dan menghitung total uang yang terkumpul. Sistem ini diharapkan mampu membantu untuk menghitung dan memilah uang logam atau uang koin secara otomatis.

\section{KaJian PUSTAKa}

Darmawan Prastya pada penelitiannya yang berjudul "Rancang Bangun Alat Penghitung Uang Logam Yang Terhubung Dengan Komputer Untuk Proses Data Basenya" Dengan Tabungan Berbasis mikrokontroler ATMEGA 8535, alat ini mempermudah dalam menabung uang dan bisa dipantau berapa uang yang telah ditabung. Sensor yang digunakan yaitu photodioda yang disusun sesuai diameter uang logam. Apabila uang logam Rp.500, Rp.1000 dimasukan, maka sensor photodioda akan mengirimkan data ke IC Mikrokontroler. Setelah data hasil pengukuran uang logam didapatkan, maka data tersebut akan diproses oleh IC Mikrokontroler kemudian dijumlahkan hasilnya dan ditampilkan melalui program Visual Basic. [1]

Penelititan Sari Karyanto yang berjudul "Prototipe Mesin Penyeleksi dan Penghitung Uang Logam Berbasis Mikrokontroler ATMEL AVR AT90S8515". Penelitian ini bertujuan mengembangkan konsep mekatronika penghitung uang kertas untuk diterapkan pada uang logam. Penerapannya berupa hasil tampilan dalam jumlah satuan rupiah pada LCD dan bukan angka jumlah satuan oleh seven segment. Pembuatan perangkat keras dan lunak dari prototipe mesin penyeleksi dan penghitung uang logam ini berbasis mikrokontroler AVR AT9058515. Metode yang digunakan untuk penyeleksian dan penghitungan pada penelitian ini yaitu tiap-tiap jenis pecahan nominal dari uang logam tersebut dibuat dengan dimensi yang berbeda-beda pula sesuai nilai nominalnya, perbedaannya adalah ketebalan dan diameter dari masingmasing pecahan untuk jenis bahan yang sama. Untuk pecahan nominal 50-an memiliki dimensi yang terkecil, berturut-turut sampai yang berdimensi terbesar, yaitu pecahan nominal 1000-an. Perbedaan dimensi dari tiap-tiap jenis pecahan nilai nominal ini bisa diidentifikasi secara elektronik, terutama diameternya. Hasil yang diperoleh pada penelitian ini adalah prototipe yang mampu membedakan dan menghitung empat jenis uang logam tertentu dalam satuan rupiah, namun masih memiliki keterbatasan seperti kecepatan perhitungan dan 4 jenis uang yang dapat dihitung. [2]

Penelitian berikutnya oleh Ray Anthony C. Reyes dkk, yang berjudul "Coin Sorting and Counting Machine". Metode penyortiran dan perhitungan pada penelitian ini adalah dengan sebuah piringan yang berputar dimana terdapat lubang sesuai dengan diameter koin. Piringan ini diputar oleh motor AC, bagian ini juga merupakan jalan masing-masing koin ke wadah. Sensor phototransistor yang terletak disetiap jalur koin berfungsi untuk menghitung koin tersebut, PIC 16f877 digunakan sebagai mikrokontroler [3]. 


\section{A. Arduino UNO}

Arduino adalah suatu development board mikrokontroler, yang dirancang untuk memudahkan dalam membuat prototipe atau bahkan hingga produk jadi. Modul elektronik lain juga dapat digabungkan dengan Arduino sehingga menjadi lebih effisien. [4] Arduino Uno adalah salah satu jenis Arduino yang paling banyak digunakan oleh para hobi elektronika, dengan menggunakan mikrokontroler ATmega328. Arduino uno memiliki 14 digital General purpose input output (GPIO) dengan 6 pin diantaranya dapat digunakan sebagai output PWM, terdapat 6 pin analog input, pin ICSP yang berfungsi untuk memprogram Arduino dengan software lain, dan juga memiliki port USB tipe B. [5]

Tabel 1. Spesifikasi Arduino

\begin{tabular}{|l|l|}
\hline \multicolumn{1}{|c|}{ Parameter } & \multicolumn{1}{c|}{ Spesifikasi } \\
\hline Tegangan Operasi & $5 \mathrm{~V}$ \\
\hline Tegangan Input (rekomendasi) & $7-12 \mathrm{~V}$ \\
\hline Tegangan Input (limit) & $6-20 \mathrm{~V}$ \\
\hline Pin Digital I/O & 14 pin (6 pin Output PWM) \\
\hline Pin Analog Input & 6 pin \\
\hline Arus DC tiap Pin I/O & $20 \mathrm{~mA}$ \\
\hline Arus DC pin 3.3V & $50 \mathrm{~mA}$ \\
\hline Flash Memory & $32 \mathrm{~KB}$ (Atmega 328) 0.5 KB digunakan untuk \\
& bootloader \\
\hline SRAM & $2 \mathrm{~KB}($ ATMega328P) \\
\hline EEPROM & $1 \mathrm{~KB}($ ATMega328P) \\
\hline Clock Speed & $16 \mathrm{HZ}$ \\
\hline Panjang & $68.6 \mathrm{~mm}$ \\
\hline Lebar & $53.4 \mathrm{~mm}$ \\
\hline Berat & $25 \mathrm{~g}$ \\
\hline
\end{tabular}

\section{B. Sensor TCRT5000}

Sensor TCRT500 adalah sensor yang terdiri dari inframerah (transmitter) dan fototransistor (receiver) terpadu dalam satu modul. Phototransistor adalah salah satu jenis transistor dengan kaki basisnya berupa komponen fotokonduktif, ini membuat fungsi dari kaki basis dapat diatur sesuai dengan besarnya intensitas cahaya yang diterima oleh fotokonduktif. Cara kerjanya yaitu ketika phototransistor tidak menerima cahaya maka phototransistor tidak aktif, sehingga aliran arus (I) tidak mengalir dari kolektor (C) menuju emiter (E) sehingga Vout tinggi. Ketika menerima cahaya maka phototransistor aktif, sehingga Vout rendah. [6]

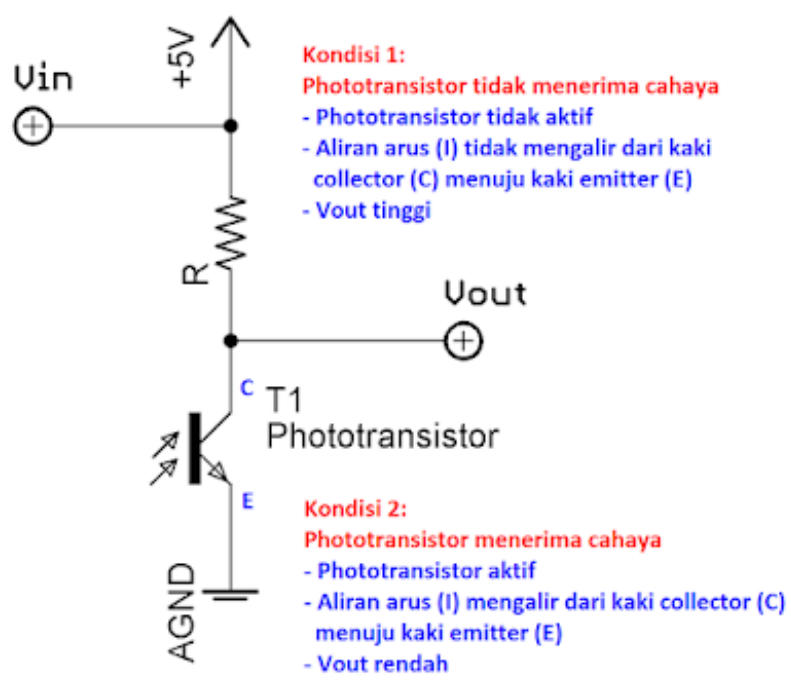

Gambar 1. Cara kerja Phototransistor 
Tabel 2. Spesifikasi TCRT5000

\begin{tabular}{|l|l|}
\hline \multicolumn{1}{|c|}{ Nama } & \multicolumn{1}{c|}{ Keterangan } \\
\hline Sensing Distance & $0.591 "(15 \mathrm{~mm})$ \\
\hline Sensing Method & Reflective \\
\hline Output Type & Phototransistor \\
\hline Voltage - Collector Emitter Breakdown (Max) & $70 \mathrm{~V}$ \\
\hline Current - Collector (Ic) (Max) & $100 \mathrm{~mA}$ \\
\hline Current - DC Forward (If) & $60 \mathrm{~mA}$ \\
\hline Operating Temperature & $-25^{\circ} \mathrm{C} \sim 85^{\circ} \mathrm{C}$ \\
\hline Mounting Type & Through Hole \\
\hline Package / Case & PCB Mount \\
\hline Packaging & Tube \\
\hline Lead Free Status & Lead Free \\
\hline RoHS Status & RoHS Compliant \\
\hline
\end{tabular}

\section{Uang Logam}

Uang logam Rupiah biasanya terbuat dari bahan alumunium atau nikel. Setiap kepingnya memiliki tekstur tertentu pada sisi uang untuk membedakan tiap pecahan. Setiap kepingnya memiliki gambar timbul dibagian depan dan belakang yang mewakili ciri khas kebudayaan dan kekayaan Indonesia [7].
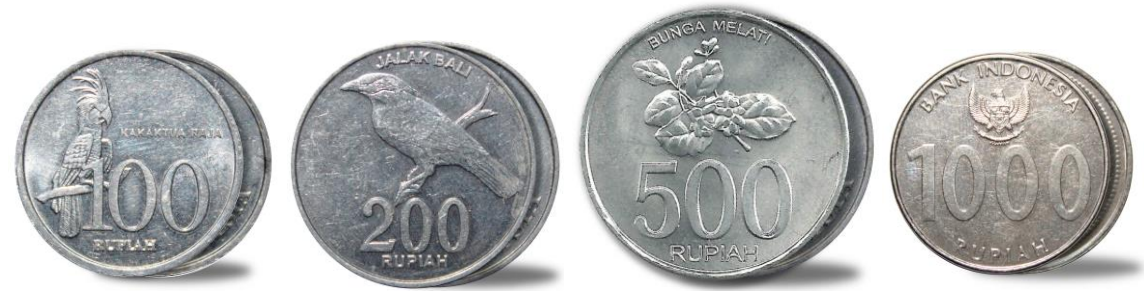

Gambar 2. Uang Logam Rp100

Pada gambar 2 merupakan bentuk uang logam Rp.100, 200, 500 dan 1000 rupiah.

Tabel 3. Spesifikasi Uang Logam

\begin{tabular}{|c|l|l|l|l|c|}
\hline Pecahan & \multicolumn{1}{|c|}{ Bahan } & Berat & \multicolumn{1}{|c|}{ Diameter } & \multicolumn{1}{|c|}{ Tebal } & $\begin{array}{c}\text { Tahun } \\
\text { Terbit }\end{array}$ \\
\hline 100 & Alumunium & $1.38 \mathrm{gr}$ & $20.00 \mathrm{~mm}$ & $2 \mathrm{~mm}$ & 1999 \\
\hline 200 & Alumunium & $1.79 \mathrm{gr}$ & $23.00 \mathrm{~mm}$ & $2.30 \mathrm{~mm}$ & 2003 \\
\hline 500 & Alumunium & $3.10 \mathrm{gr}$ & $27.000 \mathrm{~mm}$ & $2.50 \mathrm{~mm}$ & 2003 \\
\hline 1000 & Nikel Plated Steel & $4.50 \mathrm{gr}$ & $24.15 \mathrm{~mm}$ & $1.6 \mathrm{~mm}$ & 2010 \\
\hline
\end{tabular}




\section{Metode Penelitian}

Metode penelitian pada jurnal ini disusun berdasarkan flowchart berikut ini:

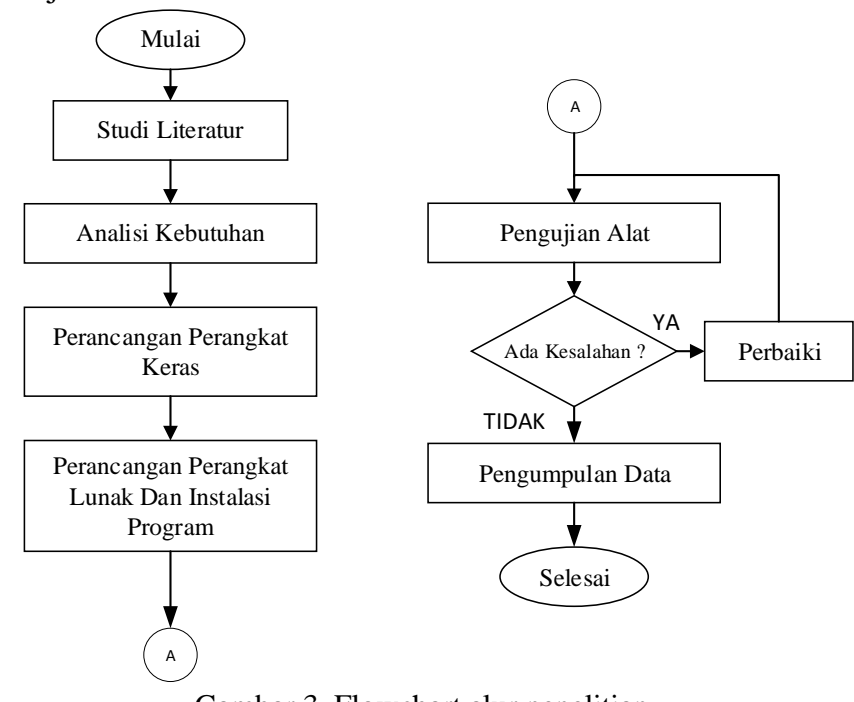

Gambar 3. Flowchart alur penelitian

Alur penelitian ini diawali dengan studi literatur, dimana pada tahap ini dilakukan pengumpulan data referensi baik dari buku maupun jurnal terkait dengan topik. Kemudian dilanjutkan dengan analisis kebutuhan baik itu kebutuhan fungsional maupun non fungsional. Perancangan perangkat keras ini dilakukan untuk mempermudah proses yang dilakukan secara bertahap. Perancangan perangkat lunak dan instalasi program, dimana pada tahap ini dibuat flowchart perancangan perangkat lunak. Selanjutnya pengujian alat dimana tujuannya untuk menguji alat yang telah dibuat apakah sesuai dengan yang diharapkan dan dapat berfungsi dengan baik. Tahap selanjutnya dilakukan dengan menguji setiap bagian blok sistem, apabila terjadi kesalahan maka akan lakukan perbaikan dan dilakukan pengujian ulang sampai tidak terjadi kesalahan lagi. Tahap terakhir adalah pegumpulan data yang diperoleh dari pengujian sistem.

\section{A. Blok Diagram Sistem}

Blok diagram dari sistem yang dibuat ditunjukkan pada gambar berikut:

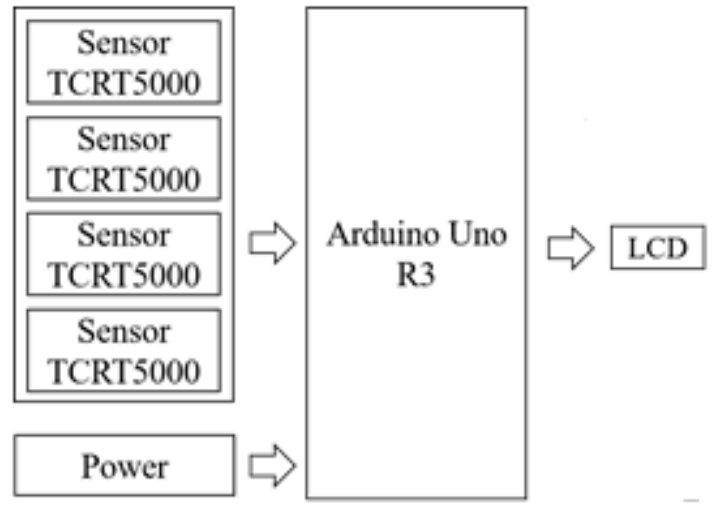

Gambar 4. Blok Diagram Sistem

Gambar 4 menunjukkan blok diagram sistem penghitung dan penyortir uang logam berbasis arduino Uno. Tegangan suplay sistem didapat dari blok power suply. Terdapat 4 buah sensor TCRT5000 yang masingmasing sensor di set untuk mendeteksi uang logam yang masuk sesuai dengan diameter uang logam. Hasil deteksi tersebut dibaca mikrokontroler kemudian akan dihitung jumlah uang logam yang terdeteksi dan ditampilkan ke LCD display. 

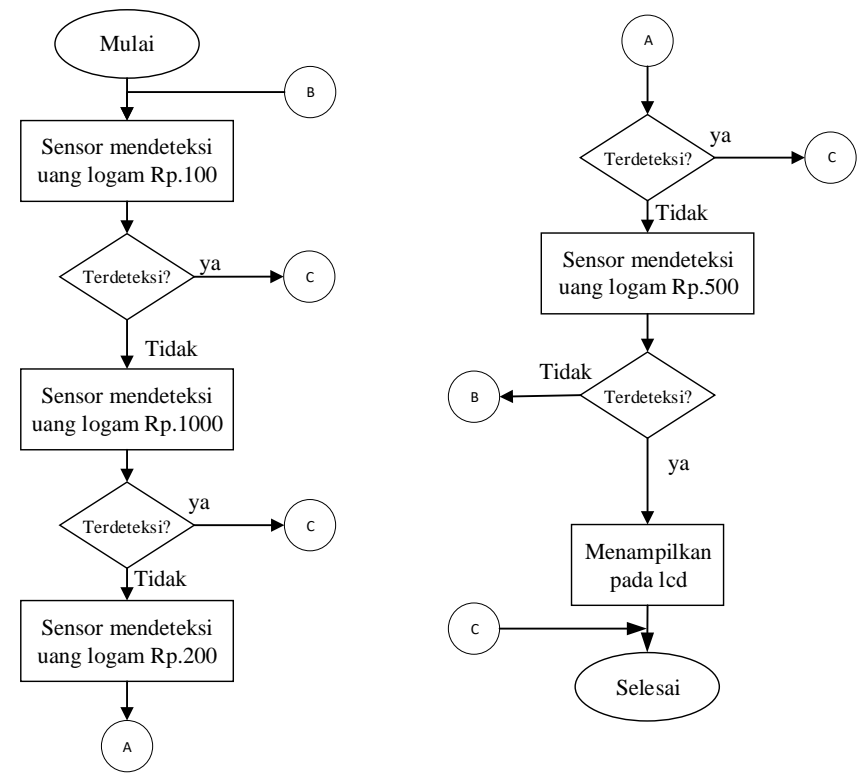

Gambar 5. Flowchart Alur Perangkat lunak mikrokontroler

Pada gambar 5 menunjukan alur kerja dari mikrokontroler sesuai dengan aplikasi yang dirancang. Mikrokontroler akan berjalan dan melakukan tindakan sesuai dengan program yang diberikan. Pada proses pertama mikrokontroler sensor TCRT5000 mendeteksi uang logam kemudian nominal uang ditampilkan pada LCD.

\section{HASIl DAN DiSKUSI}

Bagian ini akan menjelaskan mengenai hasil yang didapat dari sistem yang telah dirancang. Gambar 6 ditunjukkan desain dari alat secara keseluruhan, box yang digunakan terbuat dari bahan triplek. Pada sisi depan terdapat LCD 16x2 untuk menampilkan informasi jumlah uang logam yang terdeteksi.

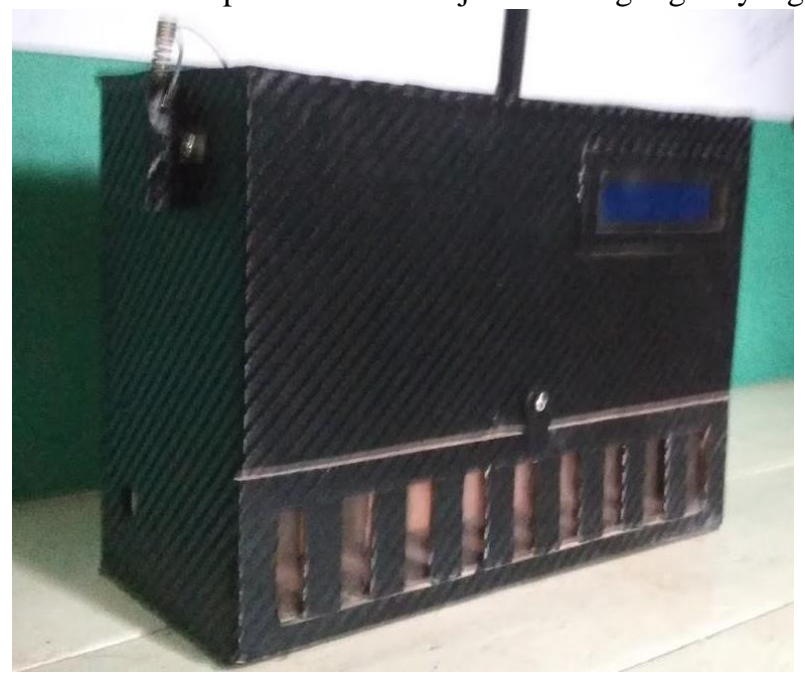

Gambar 6. Desain Alat 


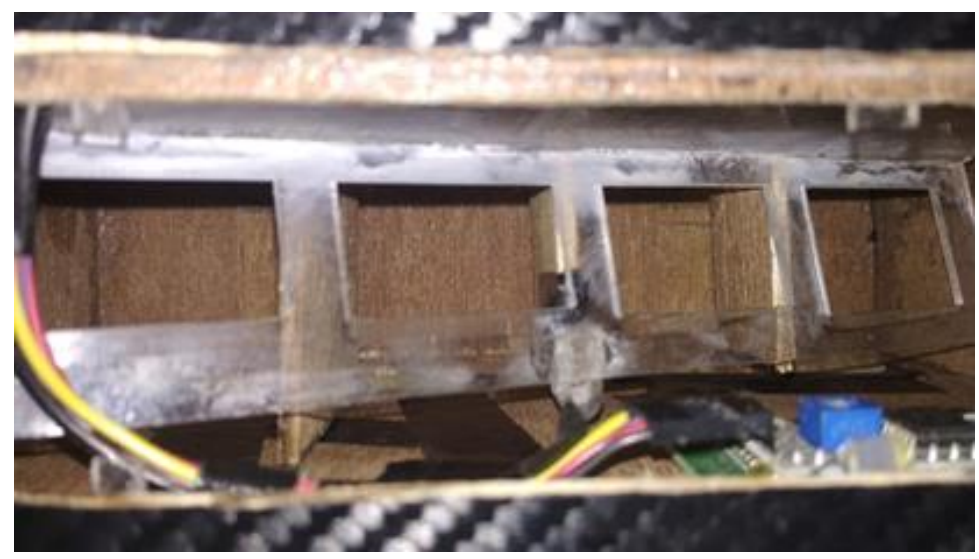

Gambar 7. Desain lubang untuk sortir uang logam

Gambar 7 merupakan papan sortir yang dirancang dari bahan akrilik untuk menyortir uang logam. Setiap lubang memiliki diameter yang berbeda - beda dan disesuaikan dengan ukuran uang logam dimulai dari diameter paling kecil (sebelah kiri) hingga diameter paling besar (sebelah kanan. Berdasarkan urutan uangnya yaitu dari Rp.100, Rp.1000, Rp.200, Rp.500. Papan tersebut di set dengan kemiringan $20^{\circ}$ agar uang logam dapat meluncur dengan lancar. Setiap lubang juga memiliki pembatas agar uang logam jatuh ke tempat penampungannya masing - masing.

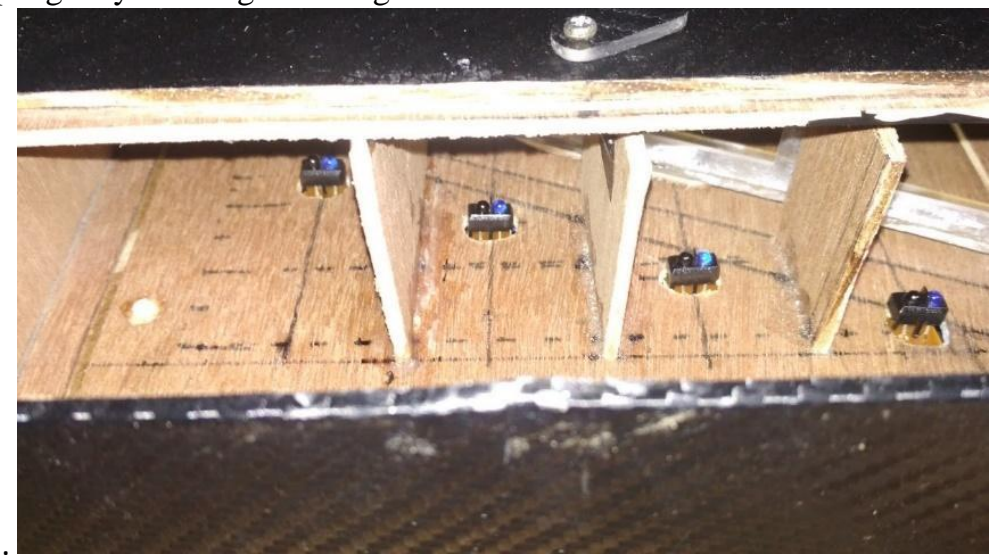

Gambar 8. Penempatan sensor TCRT5000

Posisi penempatan sensorTCRT5000 ditunjukkan pada gambar 8, setiap lubang memiliki sensor TCRT5000 yang digunakan untuk mendeteksi setiap uang logam yang jatuh,

\section{A. Pengujian Akurasi Sistem}

Pengujian akurasi pembacaan sensor dari sistem dengan cara melakukan percobaan sebanyak seratus kali pada masing - masing nominal koin dari nominal 100 hingga 1000 rupiah. 


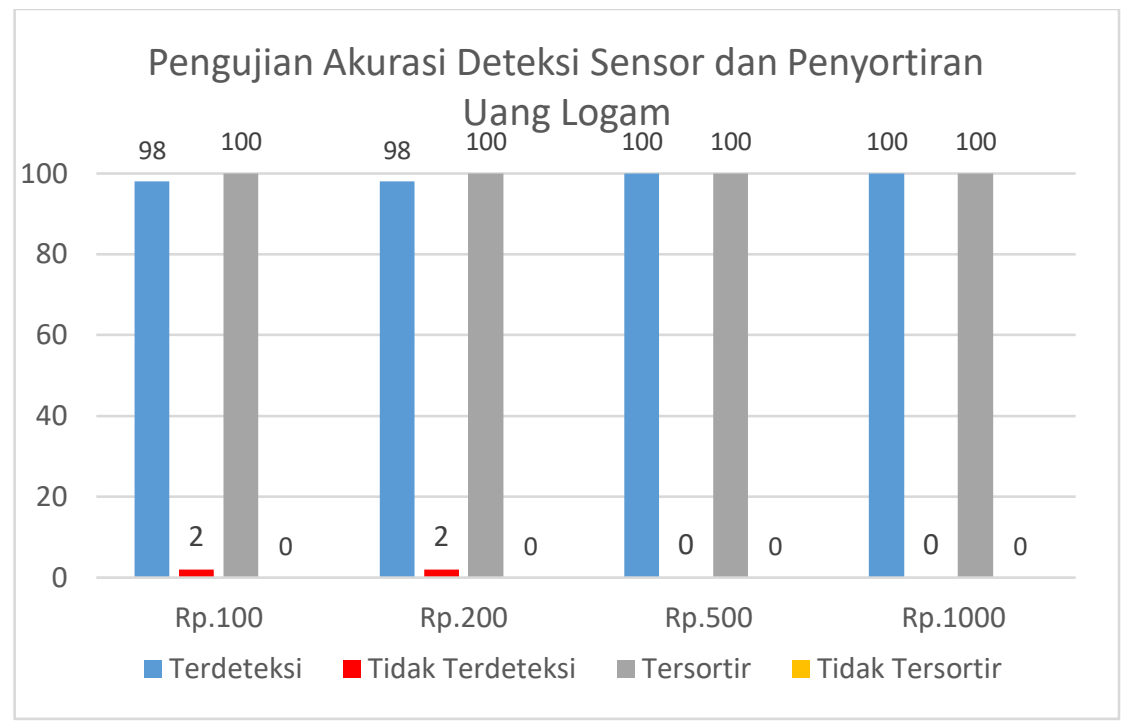

Gambar 9. Grafik Pengujian Akurasi pendeteksian dan Penyortiran Uang Logam

Grafik pengujian akurasi pendeteksian dan penyortiran uang logam ditunjukkan pada gambar 9. Dari grafik tersebut didapatkan bahwa pada pengujian uang logam Rp.100 rupiah terdapat 2 percobaan tidak terdeteksi oleh sensor dari 100 kali percobaan. Kemudian pada pengujian uang logam Rp200 rupiah terdapat juga 2 kali percobaan tidak tereteksi oleh sensor dari 100 kali percobaan. Pada pengujian uang logam Rp.500 rupiah dan Rp.1000 rupiah tidak ada kegagalan pendeteksian ataupun penyortiran. Jadi, dari pengujian tersebut dapat disimpulkan bahwa tingkat akurasi pendeteksian uang logam Rp.100 rupiah sebesar 98\%, kemudian tingkat akurasi pendeteksian uang logam Rp.200 rupiah sebesar 98\%, dan untuk pendeteksian uang logam Rp.500 rupiah dan Rp.1000 rupiah memiliki tingkat akurasi sebesar $100 \%$. Kemudian jika dilihat dari sisi penyortiran, semua koin yang diuji bisa masuk ke dalam wadah sesuai dengan diameter dan nominal, sehingga tingkat akurasi penyortiran semua uang logam memiliki tingkat akurasi $100 \%$.

\section{KESIMPULAN}

Kesimpulan dari jurnal ini yaitu uang logam disortir berdasarkan diameter, pada sebuah papan yang dilubangi berdasarkan diameter masing - masing uang logam tersebut. Pada masing - masing lubang tersebut diberi sensor TCRT5000 untuk mendeteksi uang logam dengan cara merefleksikan sinar inframerah pada uang logam yang tersortir kemudian diterima oleh foto transistor. Dari hasil pengujian akurasi pendeteksian uang logam Rp.100 rupiah memiliki tingkat akurasi 98\%, untuk uang logam Rp.200 memilii tingkat akurasi 98\%, Sementara tingkat akurasi untuk pendeteksian uang logam Rp.500 dan Rp.1000 adalah 100\%. Sedangkan untuk tingkat akurasi penyortiran semua uang logam memiliki tingkat akurasi yang sama yaitu $100 \%$.

\section{REFERENSI}

[1] D. Prastya, "Rancang Bangun Alat Penghitung Uang Logam Yang Terhubung Dengan Komputer Untuk Proses Data Basenya," Teknik Komputer Politeknik Negeri Sriwijaya, Palembang, 2016.

[2] S. Karyanto, "Prototipe Mesin Penyeleksi dan Penghitung Uang Logam Berbasis Mikrokontroler ATMEL AVR AT90S8515," Fakultas Teknik Universitas Diponegoro, 2011.

[3] R. Anthony C. Reyes, dkk "Coin Sorting and Counting Machine," Mapua Institute of Technology, 2008.

[4] S. Suhaeb, Buku Ajar Mikrokontroler dan Interface, Makasar, 2017.

[5] Y. D. P. Junaidi, Project Sistem Kendali Elektronik Berbasis Arduino, Bandar Lampung: AURA, 2018.

[6] T. D. Suyadhi, "Phototransistor," 4 Oktober 2014. [Online]. Available: http://www.robotikauns.net/2015/01/phototransistor.html. [Accessed 10 Oktober 2019].

[7] B. Indonesia, "Kenali Ciri-ciri Uang Rupiah Logam Anda," 19 September 2015. [Online]. Available: https://www.bi.go.id/id/rupiah/uangrupiah/Pages/Ciri_Uang_Logam.aspx. [Accessed 23 September 2019]. 